\title{
Z myślą o przyszłości \\ Baumanowskie inspiracje dla pedagogiki i edukacji
}

\author{
With regard to the future \\ Bauman's inspirations for pedagogy and education
}

\begin{abstract}
A B S TRACT: The Author provides an overview of educational plots appearing in the works of Zygmunt Bauman, which inspire further pedagogical search. The article involves two parts: the first one is presenting chosen standpoints of the Polish sociologist concerning the future, i.a. the lack of long-term projects and visions, lack of prognosis possibility, downfall of citizen's engagement, perspective of social degradation. The second part discusses the postulates and challenges posed by Bauman in relation to educational policy and pedagogical practice. The imaginations of a desired future, accompanied by a pessimistic view of the present world, led the sociologist to the search for solutions to the crisis. One solution he envisioned was rooted in education and learning.
\end{abstract}

KEYWORDS: Education, youth, future visions, Zygmunt Bauman.

STRES Z C ZE N IE: Autor dokonuje przeglądu wątków edukacyjnych przewijających się w pismach Zygmunta Baumana, które stanowią inspirację do dalszych pedagogicznych poszukiwań. Artykuł składa się z dwóch części: pierwsza przedstawia wybrane stanowiska polskiego socjologa dotyczące przyszłości, w tym odnoszące się m.in. do braku długoterminowych projektów i wizji oraz możliwości prognozowania, upadku zaangażowania obywatelskiego czy perspektywy degradacji społecznej; w drugiej części autor omawia postulaty i wyzwania stawiane przez Baumana przed polityką edukacyjną i praktyką pedagogiczną. Wyobrażenia o pożądanej przyszłości, przy jednoczesnym pesymistycznym obrazie współczesności, prowadziły socjologa do poszukiwań dróg wyjścia z kryzysu. Jednej z nich upatrywał w edukacji i uczeniu się.

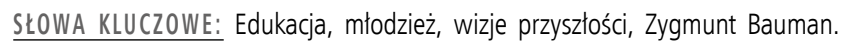




\section{Wprowadzenie}

Tekst ten jest zarówno próbą rekonstrukcji wizji przyszłości zawartej w pracach Zygmunta Baumana, jak i odczytania jego koncepcji pożądanego, skutecznego modelu edukacji przygotowującej następne pokolenia do życia w świecie coraz bardziej skomplikowanym, fragmentarycznym, podlegającym nieustannym i gwałtownym zmianom. Kształt ponowoczesnego świata oraz różnorodne zjawiska dotykające całe społeczeństwa stanowią ważne pole rozważań i interpretacji polskiego socjologa. W licznych publikacjach odnosi się on także do kwestii edukacji i uczenia się. Główne z nich to: Szanse etyki $w$ zglobalizowanym świecie, O edukacji. Rozmowy z Riccardo Mazzeo oraz wykład wygłoszony na Wydziale Studiów Edukacyjnych Uniwersytetu Adama Mickiewicza w Poznaniu, pt. „Ponowoczesna szkoła życia”.

W polskiej literaturze pedagogicznej myśl Baumana jest stosunkowo dobrze znana, zarówno z tekstów źródłowych, jak i krytycznych analiz prowadzonych przez pedagogów (zob. m.in. Theiss 2016; Witkowski 1998). Wiesław Theiss (2016, s. 31), wskazując na bogactwo inspiracji płynących z książek Baumana, podkreśla, że wszelkie próby interpretacji i odczytania Baumanowskich tez zależą „od przyjmowanego stanowiska ideologicznego. Inaczej wypowie się tu zwolennik indywidualistycznego neoliberalizmu, nowej lewicy czy różnych koncepcji tradycjonalistycznych". Fundamentalna wartość płynąca z pism Baumana, która łączy przedstawicieli różnych, często skrajnych orientacji to „troska i nadzieja - idee oparte na wspólnych uniwersalnych fundamentach kultury chrześcijańskiej i zasad społecznej nauki Kościoła" (Theiss 2016, s. 32).

Perspektywa przyjęta $\mathrm{w}$ niniejszym artykule jest tożsama $\mathrm{z}$ głosem tych pedagogów i reprezentantów innych dyscyplin naukowych, którzy wypowiadają się za modelem edukacji opartym na poszanowaniu różnorodności, kreującym wrażliwość i otwartość na Innego i jego wartości, nawiązującym do pedagogicznej kategorii dialogu oraz decentracji, czyli umiejętności oglądu świata oczyma Innego. Inaczej mówiąc, jest to integralny model rozumienia świata i edukacji, upowszechniony w polskiej pedagogice m.in przez Zbigniewa Kwiecińskiego (ekologia pedagogiczna), Wiesława Andrukowicza, Ryszarda Macieja Łukaszewicza (ekologia dialektyczna), Wiktora Żłobickiego, Bogusława Śliwerskiego, Romana Schulza (edukacja holistyczna i systemowa), Rafała Włodarczyka, Adama Chmielewskiego, Adama Groblera, Marię Dudzikową (nurt propagujący ideał wiedzy zintegrowanej) (za: Gop 2015, s. 95).

W pierwszej części naszkicowano wybrane wątki z twórczości Baumana dotyczące przyszłości. O wadze, jaką przypisuje On tej perspektywie świadczy 
zdanie zamykające wydaną już pośmiertnie książkę zatytułowaną. Retropia. Jak rzadzi nami przeszłość?: „Bardziej niż kiedykolwiek przedtem jesteśmy postawieni - my ludzie, mieszkańcy Ziemi - w sytuacji albo-albo: albo wkroczymy we wspólną przyszłość, albo skończymy w zbiorowej mogile" (Bauman 2018, s. 281). Druga część tekstu odnosi się bezpośrednio do Baumanowskich refleksji o pożądanym kształcie edukacji, której „jedynym, niezmiennym celem [...] zarówno w przeszłości, obecnie, jak i na przyszłość, jest przygotowanie młodych ludzi do życia w rzeczywistości, w którą wkraczają" (Bauman 2012a, s. 31). Edukacja jest tu zatem rozumiana jako proces przygotowywania jednostek do przyszłości nieznanej, nieodkrytej. Bauman (2012a, s. 20-21) przywołuje myśl Gregora Batesona, który wyróżnił trzy poziomy edukacji:

Najniższy poziom edukacji dotyczy przekazywania informacji, która należy zapamiętać. Drugi poziom, 'deuteroedukacja', ma na celu opanowanie 'ramy kognitywnej, w która można wpisać lub wkomponować informacje zdobywane czy znajdywane w przyszłości. Ale istnieje też trzeci poziom, który polega na wyksztatceniu umiejętności rozmontowywania i przebudowywania dominującej ramy kognitywnej lub odrzucania jej całkowicie, nie zastępujac jej niczym [...]. Najniższy $z$ trzech poziomów wyróżnionych przez Batesona już się zdezaktualizowat - pamięć przeniesiono z mózgu na dyski komputerowe, pendrive’y i serwery. $\mathrm{Na}$ tomiast to, co Bateson traktowat jako zrakowaciata, a nie zdrowa, tkanke, stało się tymczasem norma $w$ procesie nauczania i uczenia się.

Opisana powyżej transfiguracja stanowi, zdaniem Baumana, sedno procesów zachodzących aktualnie w edukacji. Umiejętność zapominania, eliminacji czy lekceważenia wcześniej zdobytej i utrwalonej wiedzy liczy się bardziej niż zdolność zapamiętywania i przechowywania. Wiedza stała się konstruktem nietrwałym i przemijalnym, stawiając pod znakiem zapytania zasadność jej gromadzenia i zachowania. Informacje dezaktualizują się niemal codziennie, do tego część z nich jest niesprawdzona lub fałszywa. Z kolei zbyt duże natężenie informacji redukuje możliwości pamięci, ograniczając tym samym zdolność przystosowania i reagowania na kolejne zapotrzebowania rynku.

Niniejsza skromna próba odczytania Baumana nie jest całościowym i syntetycznym spojrzeniem na jego twórczość - niektóre kwestie i obszary potraktowane zostały marginalnie lub też całkowicie pominięte. Potencjał refleksji pedagogicznych tego myśliciela znacznie wykracza poza wątki poruszone w niniejszym tekście. Niemniej, wybrane i fragmentarycznie zaprezentowane opinie i sugestie jednego z najpoczytniejszych intelektualistów XXI w. stanowią niewątpliwie cenny kierunkowskaz w myśleniu o edukacji, jej reformowaniu i wyznaczaniu nowych dróg rozwoju. 


\section{Przyszłość w pracach Zygmunta Baumana - różnorodność kontekstów}

Obserwacja teraźniejszości, krytyczna i w całościowym odbiorze prowadząca raczej do pesymistycznych wniosków, stała się źródłem Baumanowskich refleksji, z jednej strony o pożądanym i wymarzonym, z drugiej zaś, prawdopodobnym kształcie świata w przyszłości. Optymistycznym akcentem w myśleniu o przyszłości była wiara socjologa $\mathrm{w}$ to, że świat może być inny; że istnieją alternatywne opcje rozwoju; że nie jest jeszcze za późno, by uchronić się przed ostateczną klęską. Bauman wskazywał w swoich diagnozach na liczne bolączki i paradoksy współczesnej epoki, ich potencjalne następstwa dla życia jednostek i całych społeczeństw. Jednocześnie projektował drogi i rozwiązania prowadzące do przezwyciężenia marazmu i kryzysu. Lektura jego tekstów pozwala na zrozumienie istoty ponowoczesnej rzeczywistości i konsekwencji jakie aktualne „megatrendy” niosą dla przyszłych pokoleń; umożliwia również wyszczególnienie ważnych aspektów Baumanowskiego myślenia o przyszłości.

\section{Widmo niepewności krąży nad światem}

Fundamentalną cechą współczesności jest przejście od „stałej” do „płynnej” fazy nowoczesności. Płynność uznaje Bauman (2008, s. 7) za doskonałą metaforę współczesnego świata. Epitet „płynny” ma określać charakter zachodzących zmian. Wszystko jest krótkotrwałe, epizodyczne, zmienne, fragmentaryczne. „Utrzymuje się więc powszechne poczucie losowości, czystej przygodności i zdania na łaskę losu” (Bauman 2005, s. 140). Do rangi kluczowych kategorii opisujących współczesność urastają lęk i niepewność. Oba te stany emocjonalne związane z poczuciem zagrożenia towarzyszą wszystkim mieszkańcom globu. W świecie płynnej nowoczesności nie ma od nich ucieczki.

\section{Szkoda czasu na przewidywanie i prognozowanie}

Ta wszechobecna płynność, niepewność, zmienność świata i chaos powodują, że „przewidywanie jest stratą czasu, a wszelkie prognozy są niegodne zaufania" (Bauman 2012a, s. 148). Brak możliwości przygotowania się na przyszłość stanowi nieodwołalną cechę rzeczywistości; przyszłość jest po prostu nieznana, nieokreślona, niewiadoma. Co więcej, zawodzą nawet 
próby uchwycenia związków przyczynowo-skutkowych. Popularna metafora „efektu domina” straciła swą aktualność, podobnie zresztą jak atrybuty „przystawalność” czy „fizyczna bliskość przyczyn i skutków”, które - uwikłane w światową sieć - mają charakter niemal zupełnie przypadkowy. Lokalne problemy powodowane są globalnymi strategiami, a globalne zjawiska rozwiązaniami lokalnymi. Odległości geograficzne przestały już odgrywać znaczenie. Świat stał jednym wielkim labiryntem, pozbawionym widocznej i bezpiecznej drogi.

\section{Koniec perspektywicznego myślenia, planowania i działania}

Życie jednostek oraz całych grup i zbiorowości wyznacza szereg krótkoterminowych projektów i epizodów, których liczba jest nieskończona, a kolejność nieuporządkowana. Nie łączą się one w żadne sekwencje - nie ma z góry uporządkowanej kolejności postępowania czy rozwoju. „Wszelkie długofalowe plany [...] nie budzą zaufania; długofalowe planowanie, jeśli by się go podjąć, zwiększyłoby jedynie obszar ryzyka poprzez dodanie dodatkowych zmiennych do każdego obrachunku zysków i strat czy prawdopodobieństwa sukcesu i porażki” (Bauman 2018, s. 238).

\section{Wizje i cele jako „towar deficytowy”}

W swoich rozróżnieniach między nowoczesnością a ponowoczesnością wskazywał Bauman (2008, s. 46) na odmienne cechy obu form nowoczesnego społeczeństwa, podkreślając rozkład i upadek złudzenia, jakim była wiara w ład idealny, w którym wszystko jest zaplanowane i zorganizowane, w kres drogi prowadzącej do stanu doskonałości, w przejrzystość losu człowieka, wreszcie w opanowanie i kontrolowanie przyszłości. Współcześnie zauważa socjolog - podstawowy problem stanowi deficyt celów, nie zaś środków. Zdezaktualizowały się znane i sprawdzone schematy rozwiązań i radzenia sobie z wyzwaniami. Trudności polegają nie tyle na znalezieniu środków, ile na samym określeniu i zdefiniowaniu celu. „Teraz problemem jest nieuchwytność (a nader często złudność) celów, które blakną i rozwiewają się, zanim się je osiągnie" (Bauman 2005, s. 31). Bauman zwraca uwagę na zanik myślenia utopijnego i nieobecność atrakcyjnych wizji lepszego świata. Współczesne marzenia o przyszłości dotyczą głównie kwestii indywidualnego przetrwania, która - jak wszystko inne - uległa prywatyzacji. Dostępne dziś utopie „mówią nie o lepiej urządzonej krainie, lecz o moim w tej oto, tu i teraz, krainie lepszym urządzeniu się" (Bauman 2010, s. 165). 


\section{Uwikłanie w rynek - „śmierć obywatela"}

Ważne miejsce w twórczości Baumana zajmuje problematyka konsumpcjonizmu; w kulturze konsumpcji, konsumpcja stała się celem samym w sobie. Konsumpcjonizm „prowadzi do »społecznego nieuctwa« - zniechęca do nabywania umiejętności wspólnego z innymi szukania wyjścia z kłopotów poprzez dyskusje i negocjacje, wpajając ludziom przekonanie, że podczas najbliższej wyprawy do sklepów sami znacznie mniejszym wysiłkiem i kosztem znajdą poszukiwane rozwiązanie" (Bauman, Tester 2003, s. 145). Konsekwencje wszechobecnego konsumpcjonizmu to brak zaangażowania w sferę publiczną, ucieczka obywatela w stronę indywidualizmu, odgradzanie się od współobywateli. Bauman pisze wprost, że narodziny konsumenta oznaczają śmierć obywatela, jego narastającą bierność i apatię. „Konsument jest wrogiem obywatela" (Bauman 2007b, s. 233). Indywidualizm obywatela objawia się w wolności rynkowej oraz pielęgnowaniu własnego ,ja”, w udziale w wolnej grze rynkowej, decyzjach o zakupach i wzbogacaniu się.

\section{Perspektywa degradacji społecznej}

„Los wyrzutka” przypada, zdaniem Baumana, całemu pokoleniu młodzieży. Wpajane przekonanie o sukcesie, który jest w zasięgu człowieka, stało się złudzeniem. Każda epoka i każda zmiana przynoszą kolejnego wyrzutka, bowiem nagłe przeobrażenia wymagają umiejętności przystosowania się i radzenia sobie w nowych, nieznanych warunkach, a nie każdy taką umiejętność posiada i dlatego nie każdy może zachować wcześniej posiadany status. Poprzednio stosowane rozwiązania czy postawy nie gwarantują dziś osiągnięcia upragnionych skutków. Powszechnie pewna część pokolenia nie radziła/nie radzi sobie z następstwami zmian, „jednakże nieczęsto zdarza się, że los wyrzutka przypada całemu pokoleniu. A być może tego właśnie jesteśmy świadkami obecnie" (Bauman 2012a, s. 53). Młodych ludzi nie przygotowano na perspektywę życia w ciągłej niepewności, brak bezpieczeństwa i nieustanne zagrożenia. Zygmunt Bauman (2012a, s. 54) właśnie $\mathrm{w}$ ludziach młodych, opuszczających uczelnie widzi „pierwsze powojenne pokolenie, które ma przed sobą perspektywę degradacji społecznej”. Dodaje, że „zadziwiająco duża część tego pokolenia faktycznie wypadła, lub sądzi, że wypadła $z$ rozpędzonego pojazdu i to raz na zawsze" (Bauman 2005, s. 30). Zauważa, że pokolenie to „raczej otwarcie boi się utraty pozycji społecznej, osiągniętej przez ich rodziców, niż ma nadzieję, na jej poprawę; 
większość milenialsów przewiduje, że przyszłość przyniesie im pogorszenie warunków życia, zamiast otworzyć drogę do stopniowej ich poprawy" (Bauman 2018, s. 102). Perspektywa zastąpienia ludzi przez roboty, a w konsekwencji wykluczenie zawodowe oznaczające życiową marginalizację i pauperyzację milionów młodych wchodzących na rynek pracy, staje się coraz bardziej realna. Bauman (2018, s. 107) przekonuje, że nadzieja na kontrolowanie przyszłości jest złudna, i kreśli wizję, która wywołuje grozę: „przeznaczona jest nam rola pionków na szachownicy należącej do kogoś innego, w grze prowadzonej przez kogoś innego, kogo nie znamy i nigdy nie poznamy. Z tej przyczyny prawdziwą ulgę przynosi powrót [...] do znanego i wygodnego świata pamięci". Maria Mendel i Wiesław Theiss (2019, s. 13) wskazują na alternatywne następstwa dokonanych wyborów: „powrót może być zatem niszczący, stanowiący wyraz obronny status quo opierającego się na niesprawiedliwości. Może też być budujący, gdyż towarzyszy mu tworzenie się nowych podmiotowości i politycznych reprezentacji”.

Naszkicowany przez Baumana obraz rzeczywistości prowadzi do pesymistycznych konkluzji. W świecie zupełnie nieprzewidywalnym, pozbawionym perspektywicznych projektów i obywatelskiego zaangażowania, wiara w mityczne „lepsze jutro" musi być wątła i pozbawiona racjonalnych, logicznych przesłanek. Autor jednak (tu pojawia się optymistyczny wymiar Jego twórczości) nie pozostawia czytelnika z samymi pytaniami, wątpliwościami czy lękami. W swoich tekstach wskazuje na możliwości i szanse przezwyciężania kryzysu.

\section{Implikacje dla pedagogiki i edukacji Baumanowskie refleksje i postulaty}

Znaczna część recept na schorzenia współczesnego świata wystawianych przez Baumana odnosi się do edukacji. Część z nich jest już silnie zakorzeniona w świadomości teoretyków, naukowców, ekspertów i zaangażowanych obywateli; nie stanowi innowacyjnych idei, a jedynie umacnia w przekonaniu o ich potencjale oraz zasadności implementowania proponowanych rozwiązań i strategii. Niektóre rzucają światło na nowe wyzwania, co nie może zaskakiwać, skoro ich Autora uznaje się za jednego z najwybitniejszych interpretatorów i najwnikliwszych obserwatorów współczesności. Bauman (2000b, s. 153-154) podczas jednego z wykładów powiedział o sobie, że nie jest zawodowym pedagogiem; zauważył ponadto, że sprawy, które porusza w gronie „zawodowych” pedagogów i filozofów wychowania stały się już przedmiotem wszechstronnych analiz polskich teoretyków zajmujących się edukacją. W Baumanowskich refleksjach i postulatach tkwi niewątpliwie spory potencjał peda- 
gogiczny - podpowiada On nie tylko jak powinna wyglądać „skuteczna edukacja”, ale demaskuje też powszechnie przyjęte stanowiska i założenia. Lista jego sugestii zawiera cenne wskazówki dla wszystkich podmiotów zainteresowanych edukacją, reformowaniem szkoły i poszukiwaniem innowacyjnych, efektywnych ścieżek uczenia się.

\section{Całożyciowa edukacja obywatelska}

Bauman (2007b, s. 229) stwierdza, że o ile „edukacja i uczenie się mają się do czegoś przydać, to muszą mieć charakter ciągły i rzeczywiście trwać przez całe życie”. Idea edukacji przez całe życie cieszy się od kilku już dekad niezwykłą popularnością w świecie Zachodu; istnieje pełen konsens odnośnie do konieczności nieustannego i systematycznego uczenia się aż po sędziwą starość. Paradygmat całożyciowego uczenia się stał się dominującą wizją uczestnictwa człowieka w życiu społecznym, jednak nader często jest utożsamiany ze sferą rynkową, zawodową. Człowiek ma się stale dokształcać, podnosić swoje kompetencje, by sprostać wyzwaniom rynku, gospodarki i świata pracy. Bauman chce jeszcze czegoś więcej - uważa, że całożyciowe uczenie się musi dotyczyć obszaru obywatelskości. „Nie tylko umiejętności techniczne wymagają odnawiania, nie tylko edukacja zawodowa musi trwać przez całe życie. Tego samego wymaga, nawet w jeszcze większym stopniu, edukacja obywatelska" (Bauman 2007b, s. 232). To ona ma propagować, wśród obywateli Zachodu, znaczenie aktywności społecznej, wiedzy obywatelskiej i politycznej, ma prowadzić do rozwoju podstawowych kompetencji obywatelskich oraz odkrywać potrzebę zaangażowania w sprawy publiczne. Celem nadrzędnym edukacji całożyciowej ma być aktywizacja (inaczej „upełnomocnienie”). Jak wyjaśnia Bauman (2007b, s. 330) „'zostać upełnomocnionym' oznacza mieć możliwość dokonywania wyborów i faktycznego postępowania z nimi, a to z kolei oznacza zdolność wpływania na paletę możliwych wyborów oraz na warunki społeczne, w których się ich dokonuje”. Edukacja nie może ograniczać się do rozwoju umiejętności indywidualnych, równie ważne są kompetencje społeczne stanowiące warunek budowania kultury zaufania i solidarności. Bauman (2007b, s. 235) konstatuje „potrzebujemy edukacji przez całe życie, abyśmy mieli możliwość wyboru. Potrzebujemy jej jeszcze bardziej, aby ocalić warunki, które ten wybór czynią możliwym i realnym". Tylko całożyciowa edukacja obywatelska na rzecz budowy zaangażowanego, otwartego społeczeństwa może doprowadzić do pełnej i rzeczywistej demokracji, opartej na aktywnych i świadomych obywatelach, wyznających i respektujących cały katalog wartości demokratycznych. 
Postulaty dotyczące realizacji edukacji obywatelskiej, mimo że znane i powszechnie akceptowane, dotychczas nie doczekały się urzeczywistnienia. Grupy obywatelskie, wspólnota, sfera publiczna pozostają kategoriami zapomnianymi, zaniedbanymi, choć od początku transformacji w Polsce teoretycy wskazują na potencjał uczestniczącego obywatelstwa (zob. m.in. Przyszczypkowski 1999; Koczanowicz 2005). Polska - patrząc przez pryzmat frekwencji wyborczej, poszanowania reguł demokratycznych, respektowania praworządności i samorządności - jest przykładem kraju, w którym edukacja obywatelska wymaga niezwłocznej naprawy. Jednak w edukacji zorientowanej na kształtowanie człowieka masowego nie chodzi o krytyczne myślenie (Potulicka, Rutkowiak 2010). Zbyszko Melosik (2016, s. 42) upatruje wyjścia $\mathrm{z}$ tego ślepego zaułka, postulując „pedagogikę krytycznego myślenia i dystansu”, której „celem [...] byłoby konstruowanie kompetencji w zakresie krytycznego myślenia, a jednocześnie posiadania dystansu do rzeczywistości społecznej. Ważny byłby w niej dystans w stosunku zarówno do oferty popkulturowej, jak i dryfującej, nieograniczonej wolności (czy poczucia wolności)”.

\section{Uczenie się wspólnotowe}

Bauman wielokrotnie porusza kwestie geopolityczne. Na Europę patrzy jako na kontynent, które winien odgrywać szczególną rolę w świecie. Zdaje sobie sprawę ze znacznej przewagi militarnej, technologicznej i gospodarczej Stanów Zjednoczonych i Chin i wcale nie oczekuje rywalizacji z mocarstwa$\mathrm{mi}$, ani też bezgranicznej wiary $\mathrm{w}$ politykę sojuszników. Wyraża natomiast przekonanie, że Europa ma wyjątkową misję do spełnienia, ma szansę uczynić ten świat „duchowo i intelektualnie” lepszym. W różnorodności i „obfitości różnic" dostrzega Bauman jej największy walor. Ją też obarcza obowiązkiem przekazania obywatelom sztuki uczenia się od siebie nawzajem. Jak zauważa, w Europie, jak nigdzie indziej w świecie, ten mityczny „Inny” zawsze znajduje się blisko, nieopodal, niemalże na wyciągnięcie ręki. Uczenie się od siebie nawzajem ma wzmacniać deficytowe dziś wartości: solidarność, życzliwość, poszanowanie i zrozumienie inności. Potrzeba bezustannego i codziennego doskonalenia się, uczenia i praktykowania współżycia z obcymi i ich odmiennością jest nieuchronna (Bauman 2012a, s. 11). Już na początku lat 90. XX w. Bauman (2000a, s. 365) zadawał pytanie, czy Europa, „która nawykła do nauczania i pouczania [...] potrafi także się uczyć”. Za wielki grzech uważa odgradzanie się i odwracanie plecami od potrzebujących i poszkodowanych, wykluczonych i ofiar globalizacji finansowej. Zarzuca Europejczykom „szczelne zamykanie wrót Europy i powstrzymywanie się od jakichkolwiek działań 
mogących poprawić sytuację, która skłoniła imigrantów do opuszczenia swoich krajów" (Bauman 2007b, s. 311). Socjolog wzywa do większej odpowiedzialności i solidarności: „Ludzkość znalazła się w kryzysie - a wyjście z niego prowadzi przez międzyludzką solidarność" (Bauman 2016, s. 26). Gros polskich pedagogów podziela stanowisko Baumana. Maciej Tanaś (2006, s. 7576) odnotowuje:

wychowujemy do wojny - agresji i gwattu, a nie zachowan właściwych dla okresu pokoju. Wystarczy popatrzeć, jakimi grami fascynuja się nasze dzieci, jakie treści medialne docieraja do młodego człowieka, wtedy wszystko staje się jasne. Zwróćmy też uwage na okna domów 'niebieskie od telewizorów'. Ujawnia się w nich okrutna prawda o ludziach, którzy niegdyś czuli się połówkami tego samego jabt$k a$, a dziś siedza obok siebie przed ekranem, przeżywajac losy telewizyjnych bohaterów, sobie obcy, nie usilujacy nawet siebie zrozumieć.

Jak w świetle takich zjawisk odnieść się do kategorii podmiotowości, o którą nieustępliwie dopominają się nauki humanistyczne i społeczne? Podmiotowość wiąże się we współczesnych dyskursach prowadzonych przez przedstawicieli nauki m.in. ze świadomością związków jednostki ze światem zewnętrznym, rozumieniem otoczenia i sytuacji w nim powstających (Lewowicki 1994, s. 59), ze zdolnością do wykrywania związków przyczynowo-skutkowych między zjawiskami i roli własnych zachowań w ich generowaniu (Kofta 1989, s. 38-39). Podmiotowość jest antonimem uprzedmiotowienia, wyrazem dążności do upełnomocnienia jednostki. W dyskursie naukowym i politycznym toczonym $w$ dobie rozkwitającej kultury indywidualizmu nasila się troska o obywatelskość i demokratyczną partycypację (Hołyst 2015). W obliczu deficytu edukacji obywatelskiej jest ona $\mathrm{w}$ pełni zasadna, bo chodzi przecież o kompetencję dokonywania racjonalnych wyborów rzutujących na przyszłość, o to, by nie ulegać kuszącym, aczkolwiek nieziszczalnym propozycjom. Bułgarski politolog, Iwan Krastew (2018, s. 44-45), zauważa, że:

w odróżnieniu od Kościoła katolickiego czy dawnych komunistów, nowi populiści nie proponuja żadnego wymiaru katechetycznego czy pedagogicznego [...]. Ambicja nowego populizmu jest popieranie ludzi bez żadnego przyszłościowego projektu. W tym sensie jest to doktryna idealnie dopasowana do oczekiwań społeczeństw, których obywatele sa przede wszystkim konsumentami postrzegającymi swych przywódców jako kelnerów mających jak najsprawniej spełniać klienckie życzenia. 
Wizjonerów wypierają populiści, karmiący obietnicą eliminacji wszelkich sprzeczności i bolączek, gwarantujący dobrobyt i bezpieczeństwo, świat stabilny i przewidywalny, proste i szybkie rozwiązania skomplikowanych problemów o złożonych przyczynach i wielorakich źródłach. Bauman konsekwentnie przed nimi ostrzega, demaskując proponowaną przez nich „drogę na skróty” jako „drogę donikąd”. Obrazuje to chociażby narracja antyimigrancka, sugerująca, że bez przybyszów świat będzie bezpieczniejszy i wolny od niepewności (Bauman 2010, 2016).

\section{Edukacja - otwartość - człowieczeństwo}

Nieustanne zmiany, konieczność dokonywania wyborów i przystosowania się w erze wszechobecnego ryzyka i strachu wymagają odpowiednich kompetencji i umiejętności. „Aby przygotować się do niej (ja - do przyszłości), potrzebują wskazówek i instrukcji; praktycznej, konkretnej wiedzy możliwej do zastosowania [...]. Aby spełnić ten warunek "praktyczności« dobre szkolnictwo musi stymulować i propagować otwartość, a nie zamykanie się umysłu” (Bauman 2012a, s. 31). Tylko osoby otwarte na innych, na pojawiające się szanse i możliwości, posiadające zdolności działania i podejmowania właściwych wyborów, mają szanse na sukces. Bauman przywołuje Hannę Arendt (1986, s. 61; za Bauman 2007b, s. 346), która twierdziła, że „otwarcie na innych ludzi, jest warunkiem przedwstępnym człowieczeństwa w każdym ze znaczeń tego przebogatego w treści słowa". W tym sensie, otwartość to fundamentalna, konstytutywna cecha człowieczeństwa, wykraczająca w swojej istocie poza konteksty rynkowe i zawodowe, ogarniająca wszelkie aspekty ludzkiego bycia w świecie. Bauman jest przekonany, że edukacja musi być otwarta, że musi uczyć otwartości, inaczej nie wskrzesi w ludziach empatii i odpowiedzialności. W podobnym tonie wypowiada się Jerzy Brzeziński (2010, s. 223-224), który apeluje:

Dziś nam, jak nigdy dotychczas, potrzebny jest 'uniwersytet otwarty', występujacy przeciwko ksenofobii, dogmatyzmom i nietolerancji, uniwersytet pluralistyczny, rozumiejący i empatyczny. [...] Uniwersytet musi, właśnie w imię swojej wielowiekowej misji, podjać zadania formacyjne - nie mniej ważne od zdobywania wiedzy naukowej $i$ ksztaltowania umiejętności. Jedno $z$ tych zadań wiąże się $z$ ksztaltowaniem postawy pluralizmu - zarówno $w$ badaniach naukowych, jak $i w$ życiu codziennym.

W swoich tekstach Bauman wielokrotnie nawołuje do globalnej odpowiedzialności i solidarności. Obywatel powinien „traktować społeczeństwo jako teren współodpowiedzialności i twórczego wysiłku” (Bauman 2007b, s. 372). 
Człowiek to przecież istota społeczna, która żyje wśród i dla innych ludzi, a zatem swój wysiłek winna ukierunkować na sprawy wspólnotowe, nie zaś na wąsko pojęty interes jednostki. To przesłanie, pełne odpowiedzialności moralnej i troski wspólnotowej, stanowi jeden z kluczowych wątków w twórczości Baumana. W świecie nagradzającym skrajny indywidualizm i egoizm głosy zachęcające do braterstwa i solidarności są nader często lekceważone.

\section{„Wiedza nie daje sukcesu, a edukacja nie prowadzi do wiedzy"}

Edukacja nie odpowiada na wyzwania płynnej nowoczesności i nie potrafi zapewnić wszystkim dobrego życia. Bauman (2012a, s. 48). przypomina „że wszyscy lub niemal wszyscy współcześni bohaterowie historii typu 'od pucybuta do milionera', do których uśmiechnęło się szczęście i zbili miliardowe majątki na jednym fortunnym pomyśle [...] nie mają pełnego wykształcenia [...]. To oni właśnie ucieleśniają ideę udanego życia”. Ta prawidłowość nie ma jednak sugerować rezygnacji z dążeń do zdobycia jak najwyższego i możliwie najlepszego jakościowo wykształcenia. Poziom wykształcenia stanowił od dawna instrument selekcji i narzędzie segregacji w walce o najatrakcyjniejsze miejsca pracy. Dziś jednak ani wykształcenie, ani gotowość do pełnego poświęcenia się pracy nie gwarantują sukcesu. Merytokratyczne założenia stojące u podstaw systemu niewiele znaczą $\mathrm{w}$ kontekście całej rzeszy dobrze wykształconej a bezrobotnej młodzieży. „W naszych społeczeństwach, w których gospodarkę napędzają rzekomo wiedza i informacja a edukacja gwarantuje sukces ekonomiczny, obserwujemy, że wiedza nie daje sukcesu, a edukacja nie prowadzi do wiedzy" (Bauman 2012a, s. 80). Bauman podkreśla nieadekwatność pozyskiwanej formalnej wiedzy do zapotrzebowania rynku pracy. Mimo coraz wyższego poziomu nauczania, obserwuje się deficyt pożądanych kompetencji osób wchodzących na rynek pracy. „Na poziomie globalnym ujawnia się znaczne rozproszenie wiedzy formalnej [...], ale ta formalizacja nie idzie w parze $\mathrm{z}$ umiejętnością, ba, ze sztuką zarządzania konkretami, która przekształca wiedzę szkolną w codzienną praktykę" (Bauman, Leoncini 2018, s. 98).

Także pedagodzy zwracają uwagę na dominujące współcześnie pragmatyczne podejście społeczeństwa do wiedzy. Ludzie „dziś poszukują wiedzy szczegółowej i przydatnej w konkretnych okolicznościach zawodowych. Są w większym stopniu zorientowani na 'kwalifikacje' i 'umiejętności' niż na 'wiedzę, w większym stopniu na 'praktykęe niż 'teorię"' (Melosik 2000, s. 205). Wiedza, umiejętności, kwalifikacje stanowią w nieporównywalnie większym stopniu wartość instrumentalną niż autoteliczną. 
Współczesny człowiek uczy się nie, aby wiedzieć; nie aby być; nie, aby działać; nie, aby być $\mathrm{z}$ innymi, ale przede wszystkim, aby mieć dobrą pracę i pozycję zawodową, dom, samochód itp. Tymczasem zupełnie niewykorzystany pozostaje potencjał człowieka, który mógłby posłużyć do naprawy przyszłości. Harald Welzer (2016, s. 159-164), na przykładzie walki ze zmianami klimatu, wskazuje na splot przyczyn stojących na przeszkodzie perspektywicznemu myśleniu i działaniu. Po pierwsze, istnieje zbyt rozciągnięta struktura czasowa pomiędzy przyczynami a konsekwencjami, co zniechęca do działania, bowiem w najbliższej przyszłości efekty tak czy inaczej pozostaną niezauważone. Brak czytelnego związku przyczynowo-skutkowego rozmywa polityczną odpowiedzialność: „ofiary” dopiero w przyszłości przekonają się o tym, że nimi są. Po drugie, przyczyny zjawisk i problemów mają charakter złożony i rozproszony, a jeśli „wszystko wiąże się ze wszystkim, to wydaje się, że nie ma szans na uzyskanie jakiejś diagnozy, a tym bardziej na zastosowanie jakichś środków zaradczych". Po trzecie, brakuje całościowej strategii radzenia sobie z globalnymi problemami. Negocjacje i uzgodnienia pomiędzy mocarstwami nie prowadzą do żadnych realnych działań; służą tylko mamieniu opinii publicznej obietnicami walki z kryzysami. Po czwarte zaś, globalizacja stanowi dla większości ludzi fenomen abstrakcyjny, niezrozumiały i daleko wykraczający poza ich zdolności poznawcze i kompetencje. Ten ostatni argument w szczególności stanowi wyzwanie dla pedagogiki, o której „sile jako dyscypliny naukowej” - jak podkreśla Bogusław Śliwerski (2006, s. VII) - „świadczy to, że refleksyjnie, $\mathrm{z}$ wielkim dystansem i powagą racji wchłania nowości pojawiające się w naukach społecznych i humanistycznych, reagując niemalże natychmiast na zmiany społeczno-polityczne w społeczeństwach nam współczesnych i stawiając czoła ich wyzwaniom czy nadziejom".

\section{Dyplom jako iluzja sukcesu}

Mimo niskiej przydatności wiedzy zdobywanej w edukacji formalnej, także w Polsce, rozprzestrzeniły się takie zjawiska, jak: "choroba dyplomu” (Dore 1976), „ekspansja edukacyjna” (Mikiewicz 2014), „boom edukacyjny” (Sadura 2012). Upragniony dyplom uchodzi za „list uwierzytelniający” (Collins 1979), za przepustkę do świata ludzi bezpiecznych i wygranych, a zabieganie o niego oznacza tak naprawdę „walkę o dobre życie” (Melosik 2000, s. 203). „Podczas gdy kiedyś ludzie oceniali się nawzajem, patrząc na pochodzenie, to teraz istotne są dyplomy na ścianie" (Bregman 2018, s. 196). Jednak mimo widocznej „inflacji tytułów szkolnych” (Bourdieu 2005, s. 181), formalne wykształcenie - jak zauważa np. Ulrich Beck (2004, s. 227) „nie stało się wcale 
zbędne. Wprost przeciwnie: bez kwalifikacji i dyplomu nie ma w ogóle przyszłości zawodowej. Zaczyna się rozpowszechniać pogląd, że dyplomy i kwalifikacje wystarczają coraz mniej, jednocześnie są coraz bardziej konieczne, aby osiągnąć upragnione pozycje zawodowe”. Dochodzi do paradoksu, gdzie, z jednej strony dyplomy nie stanowią już gwarancji sukcesu, z drugiej, są konieczne, aby w ogóle o sukcesie marzyć. Bez nich - mówiąc językiem sportu - już na starcie mamy stratę nie do odrobienia, oddajemy mecz walkowerem, „rzucamy białym ręcznikiem", nie podejmując nawet rękawicy.

Zygmunt Bauman (2012a, s. 79) nie pozostawia złudzeń. Przekonany jest, że wiara w dyplom jako gwarancję dołączenia do grona ludzi wygranych jest już dziś bezpodstawna, a „coraz więcej absolwentów chowa dyplomy uniwersyteckie do szuflady między inne pamiątki rodzinne i zadowala się pracą niewymagającą specjalnych kwalifikacji”. Wysokie oceny, solidne wykształcenie i coraz bogatsze $\mathrm{CV}$ nie pomagają w zaspokojeniu ambicji. Na absolwentów szkół wyższych nie czekają upragnione stanowiska. Zaliczając kolejne staże, praktyki, kursy i szkolenia, mogą oni liczyć co najwyżej na otrzymanie pracy, ale nie na to, że będzie ona odpowiadać ich kwalifikacjom i oczekiwaniom. Jednak „znaczenie wyższej edukacji i dyplomów w różnicowaniu jednostek i stratyfikowaniu społeczeństw nie zmniejszy się w przyszłości. Coraz większą rolę będzie przy tym odgrywać prawdopodobnie hierarchia poszczególnych uczelni" (Gromkowska-Melosik, Gmerek 2008, s. 34). Zjawisko to w polskim systemie edukacyjnym zauważyli m.in. Zbigniew Kwieciński (2010) oraz Henryk Domański (2010), nazywając je „nowymi nierównościami edukacyjnymi”.

Dyplomy elitarnych uniwersytetów mogą gwarantować sukces; pozostałe zachowają wartość sentymentalną lub będą potęgować frustracje i rozczarowanie. $\mathrm{Z}$ drugiej strony, oczekiwania rzeszy dobrze wykształconej młodzieży mogą mieć znaczenie transformacyjne. Można mniemać, że jej ambicje i roszczenia staną się zarzewiem zmiany i impulsem do budowy alternatywnego porządku, co stanowiłoby pozytywny skutek rosnącego poziomu wykształcenia mieszkańców Zachodu. Niewykluczone, że rację ma Paul Mason (2015, s. 29), twierdząc, że „potrzebujemy całościowego przekształcenia systemu. Najlepiej wykształcone pokolenie w historii ludzkości nie zaakceptuje w przyszłości tak wysokich nierówności oraz spowolnionego rozwoju".

\section{Niezgoda na urynkowienia edukacji}

Negacja neoliberalnego podejścia do edukacji jest dość powszechna wśród polskich pedagogów. Istnieje konsens co do negatywnych konsekwencji polityki neoliberalnej dla systemu edukacji oraz obowiązku jej ochrony 
przed procesami rynkowymi (zob. m.in. Potulicka, Rutkowiak 2010; Szahaj 2015; Śliwerski 2015). Otwiera się tu szerokie pole także do debat o instytucjach edukacyjnych, do pytań o szkołę, uniwersytet i inne miejsca, w których ludzie zbierają doświadczenia, wchodzą w interakcje, uczą się. Jeśli mają uczyć się przez całe życie, muszą zmienić się również zadania i struktury klasycznych organizatorów ofert edukacyjnych. „Szkoła nigdy już nie będzie jedyną skarbnicą mądrości, ale może być wciąż istotnym miejscem jej poszukiwania" (Skrzypczak 2006, s. 65). Jednak zmiany muszą być rozumne i służyć społeczeństwu, nie zaś interesowi władzy czy grup biznesowych - akcentują krytycy współczesnego uniwersytetu i upominają się, by nie przekreślać długiej i chlubnej tradycji, ulegając doraźnym presjom i sprzeniewierzając się swojej misji. W dominującej narracji, także polityczno-oświatowej, rynek jest uznany za „siłę zdolną do kolonizacji każdej, w tym również akademickiej, sfery ludzkiego działania" (Stankiewicz 2014, s. 110). Ludzie nauki domagają się przede wszystkim wyzwolenia uniwersytetów spod nacisków ekonomicznych ze strony sponsorów i ich wpływu na charakter działalności badawczej, która winna służyć innym celom aniżeli pomnażaniu zainwestowanych przez nich środków (Brzeziński 2010).

Analogiczne stanowisko zajmuje Bauman, krytykując strategię obniżania nakładów na edukację wyższą w krajach zachodnich, wzrost opłat za studia i ekspansję szkolnictwa prywatnego. Cięcia wydatków na oświatę utożsamia z dramatycznym obniżeniem pozycji cywilizacji europejskiej; $\mathrm{z}$ wizją marginalizacji i peryferyzacji Starego Kontynentu. Bezpośrednią konsekwencją realizowanej polityki są redukcja etatów na uczelniach oraz rezygnacja $\mathrm{z}$ niekomercyjnych projektów badawczych. Znacznie bardziej społecznie dotkliwym efektem będzie wzrost nierówności społecznych, a „większa nierówność panująca $\mathrm{w}$ społeczeństwie zdaje się potęgować w ludziach lęki związane $\mathrm{z}$ oceną społeczną, gdyż sprawia, że status społeczny nabiera większego znaczenia” (Wilkinson, Pickett 2011, s. 60). Rodziny słabiej sytuowane będą z większą jeszcze powściągliwością podchodzić do inwestycji w edukację dzieci, w obawie przed rosnącym zadłużeniem i koniecznością spłacania wieloletniego, często dożywotniego kredytu. Ryzyko marnotrawstwa pieniędzy będzie zbyt duże, dlatego znaczna część rodziców ze środowisk społecznie defaworyzowanych zrezygnuje z posyłania dzieci do drogich, prywatnych szkół. Bauman (2012b, s. 219) konkluduje: „potrojenie opłat za studia nieuchronnie zdziesiątkuje szeregi młodych ludzi z upośledzonych rewirów dotkniętych społecznym i kulturowym niedostatkiem”, co doprowadzi do zubożenia społeczeństwa „o rosnącą liczbę potencjalnych brylantów, którym wyszlifowania odmówiono”. Konsekwentnie wzywa decydentów do wsparcia dla edukacji publicznej i urzeczy- 
wistnienie edukacji dla wszystkich, niezależnie od pochodzenia i statusu ekonomiczno-społecznego.

Guy Standing (2014, s. 153), popularyzator terminu „prekariat” opisującego nową klasę społeczną, nie pozostawia złudzeń: „neoliberalne państwo od jakiegoś czasu przekształca system szkolnictwa, czyniąc go stałym elementem społeczeństwa rynkowego. Przesuwa tym samym rolę edukacji w kierunku formowania 'kapitału społecznego i przygotowania do pracy'. Jest to jeden z najobrzydliwszych aspektów globalizacji”. Autor ocenia, że „utowarowienie edukacji jest chorobą społeczną" (Standing 2014, s. 160). Równie przekonująco przemawia Joseph Stiglitz (2015, s. 440), który - wśród wielu propozycji dotyczących przeobrażenia systemu społeczno-ekonomicznego - dopomina się o rozszerzenie dostępu do edukacji stanowiącej główny mechanizm awansu społecznego: „możemy pójść w odwrotnym kierunku niż ten w którym zmierzamy [...] ale będzie to wymagać podjęcia zbiorowego, ogólnonarodowego wysiłku”. Identyczny pogląd o szansach naprawy systemu, tym razem w kontekście francuskiego modelu, głosi ekonomista, Thomas Piketty (2018, s. 82): „doświadczenie pokazuje, że da się wprowadzić większą przejrzystość i zasadę równości do naszego systemu edukacyjnego, zachowując zarazem wszystkie jego mocne strony”. Istnieją zatem nie tylko alternatywne kierunki myślenia o edukacji, ale też realne strategie rozwoju edukacji publicznej.

\section{Zamiast zakończenia. Wiara w edukację}

Zygmunt Bauman nie kreśli optymistycznej wizji przyszłości, bo trudno pokładać w przyszłości nadzieję, gdy rzeczywistość pełna jest antagonizmów i dysfunkcji: „upośledzenie i upokorzenie są dziś obok rosnącej nierówności społecznej i wątlenia solidarności głównymi przyczynami sprawczymi dewastacji moralnej i źródłem społecznych konfliktów (Bauman 2010, s. 175). Ocenia, że „w dzisiejszych czasach raczej obawiamy się przyszłości, straciwszy wiarę, że jakimś sposobem, kolektywnie uda nam się załagodzić jej okrucieństwa oraz sprawić, by była mniej przerażająca i odpychająca a nieco bardziej przyjazna w obsłudze" (Bauman 2018, s. 101).

A jednak przesłanie Baumana można też odczytać jako apel o to, by się nie poddawać i nie tracić nadziei. On sam dostrzega możliwości i szanse na uczynienie świata bardziej przyjaznym i znośnym. Jedną z opcji jest edukacja promująca zaangażowanie, otwartość i solidarność. O te wartości nieustannie i konsekwentnie upominał się Bauman. Jego postawę zaangażowanego badacza można określić - stosując zwrot Gramsciego (1950) - „pesymizmem intelektu, ale optymizmem woli”. 
Próby odczytania pism wybitnego socjologa pozwalają nie tylko na głębsze rozpoznanie deficytów i sprzeczności świata; rozjaśniają także bezdroża edukacyjne. Koncepcje Baumana nie dostarczają odpowiedzi na wszystkie ważne pytania pedagogiczne, ale zawsze stanowią cenny materiał analityczny. Jego stanowiska dotyczące strategii edukacyjnych i praktyk pedagogicznych zawierają impulsy do działania, refleksji i dalszych poszukiwań. Budująca jest uwaga Baumana (2012a, s. 38):

Wydaje się, że możliwości oddziaływania wspótczesnego systemu edukacji sa zaiste ograniczone $i \dot{z}$ e coraz bardziej podporzadkowuje się on zasadom gry rynku konsumenckiego, a jednak jego przeobrażająca sita może być na tyle duża, że da się go zaliczyć do grona obiecujących czynników takiej rewolucji.

Gdzie indziej Bauman (2000b, s. 168) dodaje: „pedagogika musi poniekąd płynąć pod prąd”. Ta konstatacja powinna jej towarzyszyć na co dzień, i, co więcej, przypominać, że „wszelkie dyskusje na tematy edukacji, humanistyki polskiej i wychowania powinny się toczyć $\mathrm{z}$ uwzględnieniem tych wszystkich przeobrażeń, które zachodzą wobec nas, a także z przekonaniem, że w świecie ponowoczesnym wartości humanistyczne są zagrożone" (Faron 2006, s. 34). Co jednak nade wszystko istotne - mówi o tym maksyma Alberta Camusa: „Przyszłość będzie szczodra jedynie wtedy, kiedy wszystko ofiarujesz teraźniejszości” - nie stać ludzkości na bierność, zwłokę, opieszałość. Nie pomogą ani precyzyjne mapy, ani jednoznaczne drogowskazy, gdy nie ma woli (politycznej, społecznej, wspólnotowej), by podążyć w wyznaczonym kierunku, zaczynając "tu” i „teraz” od uczenia się praktykowania demokracji.

\section{Literatura}

Bauman Z. (2000a), Ponowoczesność jako źródło cierpień, Warszawa: Wydawnictwo Sic! Bauman Z. (2000b), Ponowoczesna szkoła życia, [w:] Z. Kwieciński (red.), Alternatywy myślenia o/dla edukacji, Warszawa: Instytut Badań Edukacyjnych, s. 151-170.

Bauman Z. (2005), Życie na przemiat, Kraków: Wydawnictwo Literackie.

Bauman Z. (2006), Społeczeństwo w stanie oblężenia, Warszawa: Wydawnictwo Sic!

Bauman Z. (2007a), Płynne czasy. Życie w epoce niepewności, Warszawa: Wydawnictwo Sic!

Bauman Z. (2007b), Szanse etyki w zglobalizowanym świecie, Kraków: Wydawnictwo Znak.

Bauman Z. (2008), Płynna nowoczesność, Kraków: Wydawnictwo Literackie.

Bauman Z. (2010), Socjalizm. Utopia $w$ działaniu, Warszawa: Wydawnictwo Krytyki Politycznej. Bauman Z. (2012a), O edukacji. Rozmowy z Riccardo Mazzeo, Wrocław: Wydawnictwo Naukowe Dolnośląskiej Szkoły Wyższej.

Bauman Z. (2012b), To nie jest dziennik, Kraków: Wydawnictwo Literackie.

Bauman Z. (2016), Obcy u naszych drzwi, Warszawa: Wydawnictwo Naukowe PWN.

Bauman Z. (2018), Retropia. Jak rządzi nami przeszłość, Warszawa: Wydawnictwo Naukowe PWN. 
Bauman Z., Leoncini T. (2018), Płynne pokolenie, Warszawa: Wydawnictwo Czarna Owca.

Bauman Z., Tester K. (2003), O pożytkach $z$ wątpliwości. Rozmowy z Zygmuntem Baumanem. Warszawa: Wydawnictwo Sic!

Beck U. (2004), Społeczeństwo ryzyka, wyd. 2, Warszawa: Wydawnictwo Naukowe SCHOLAR. Bourdieu P. (2005), Dystynkcja. Społeczna krytyka władzy sądzenia, Warszawa: Wydawnictwo Naukowe SCHOLAR.

Bregman R. (2018), Utopia dla realistów. Warszawa: Wydawnictwo Czarna Owca.

Brzeziński, J. (2010), Etos akademicki - między tradycją i wyzwaniami wspótczesności, [w:] Teksty Drugie: teoria literatury, krytyka, interpretacja, 5 (125), 227-235.

Collins R. (1979), The Credential Society, New York: Academic Press.

Domański H. (2010), Nowe ogniwa nierówności edukacyjnych w Polsce, „Studia Socjologiczne”, $1,7-29$.

Dore R.P. (1976), The Diploma Disease: Education, Qualification, and Development, Berkeley: University of California Press.

Faron B. (2006), Humanista nie powinien milczeć, [w:] K. Chmielewska (red.), Edukacja humanistyczna $w$ nowym stuleciu: rola humanistyki $w$ kształtowaniu świata wartości i postaw młodych Polaków, Wrocław: Zakład Narodowy im. Ossolińskich, s. 33-38.

Gramsci A. (1950), Listy $z$ więzienia, Warszawa: „Czytelnik”.

Gromkowska-Melosik A., Gmerek T. (2008), Problemy nierówności społecznej w teorii i praktyce edukacyjnej, Kraków: Oficyna Wydawnicza „Impuls”.

Gop A. (2015), Edukacja XXI wieku. Integralne nauczanie, „Ruch Pedagogiczny”, 4, 95-104. Hołyst B. (2015), Bezpieczeństwo społeczeństwa, Warszawa; Wydawnictwo Naukowe PWN.

Koczanowicz L. (2005), Wspólnota i emancypacje. Spór o społeczeństwo postkonwencjonalne, Wrocław: Wydawnictwo Naukowe DSWE.

Kofta M. (1989), Orientacja podmiotowa: zarys modelu, [w:] A. Gurycka (red.), Podmiotowość $w$ doświadczeniach wychowawczych dzieci i młodzieży. Wychowanek jako podmiot działań, Warszawa: Wydawnictwo Uniwersytetu Warszawskiego, s. 35-58.

Krastew I. (2018), Co po Europie?, Warszawa: Wydawnictwo Krytyki Politycznej.

Kwieciński Z. (2012), Pedagogie postu. Preteksty - Konteksty - Podteksty, Kraków: Oficyna Wydawnicza Impuls.

Lewowicki T. (1994), Przemiany oświaty, Warszawa: Wydawnictwo Akademickie „Żak”.

Mason P. (2015), Postcapitalism. A guide to our future, New York: Farrar, Straus and Giroux.

Melosik Z. (2000), Uniwersytet i przemiany kultury współczesnej, [w:] M. Cylkowska-Nowak (red.), Edukacja. Społeczne konstruowanie idei i rzeczywistość, Poznań: Wydawnictwo WOLUMIN, s. 201-208.

Melosik Z. (2016), Pedagogika i tożsamość młodzieży w kulturze kontroli i rozproszenia, [w:] Z. Melosik, M.J. Szymański (red.), Tożsamość w warunkach zmiany społecznej, Warszawa: Wydawnictwo Akademii Pedagogiki Specjalnej, s. 27-47.

Mendel M., Theiss W. (2019), Od redaktorów: Pamięć, miejsce i kategoria pamięciomiejsca w perspektywie społeczno-edukacyjnej, [w:] M. Mendel, W. Theiss (red.), Pamięć i miejsce. Perspektywa społeczno-edukacyjna, Gdańsk: Wydawnictwo Uniwersytetu Gdańskiego, s. 9-29.

Mikiewicz P. (2014), Kapitał społeczny i edukacja, Warszawa: Wydawnictwo Naukowe PWN.

Piketty T. (2018), Do urn obywatele!, Warszawa: Wydawnictwo Krytyki Politycznej.

Potulicka E., Rutkowiak J. (2010), Neoliberalne uwikłania edukacji, Kraków: Oficyna Wydawnicza „Impuls”.

Przyszczypkowski K. (1999), Edukacja dla demokracji. Strategie zmian a kompetencje obywatelskie, Toruń-Poznań: Edytor. 
Sadura P. (2012), Szkoła i nierówności społeczne, Warszawa: Fundacja Amicus Europae.

Skrzypczak M. (2006), Głos z „prowincji”, [w:] K. Chmielewska (red.), Edukacja humanistyczna $w$ nowym stuleciu: rola humanistyki $w$ kształtowaniu świata wartości $i$ postaw młodych Polaków, Wrocław: Zakład Narodowy im. Ossolińskich, s. 61-65.

Standing G. (2014), Prekariat. Nowa niebezpieczna klasa, Warszawa: Wydawnictwo Naukowe PWN.

Stankiewicz Ł. (2014), Spór o edukację wyższq w perspektywie teorii dóbr pozycjonalnych, „Teraźniejszość - Człowiek - Edukacja”, 66(2), 109-128.

Stiglitz J.E. (2015), Cena nierówności, Warszawa: Wydawnictwo Krytyki Politycznej.

Szahaj A. (2015), Inny kapitalizm jest możliwy, Warszawa: Instytut Wydawniczy Książka i Prasa.

Śliwerski B. (2006), Wprowadzenie, [w:] B. Śliwerski (red.), Pedagogika, t. 1, Gdańsk: Gdańskie Wydawnictwo Pedagogiczne, s. VII-XII.

Śliwerski B. (2015), Edukacja (w) polityce. Polityka (w) edukacji, Kraków: Oficyna Wydawnicza „Impuls”.

Tanaś M. (2006), Głos w dyskusji, [w:] K. Chmielewska (red.), Edukacja humanistyczna w nowym stuleciu: rola humanistyki $w$ kształtowaniu świata wartości i postaw młodych Polaków, Wrocław: Zakład Narodowy im. Ossolińskich, s. 74-77.

Theiss W. (2016), Solidarność globalna i zadania edukacji (Czytając Baumana), [w:] Z. Babicki, M. Kuleta-Hulboj (red.), Teoretyczne i praktyczne konteksty edukacji globalnej, Warszawa: Wydawnictwo Uniwersytetu Kardynała Stefana Wyszyńskiego, s. 17-36.

Welzer H. (2016), Samodzielne myślenie, Słupsk: Wydawnictwo Dobra Literatura.

Wilkinson R., Pickett K. (2011), Duch równości, Warszawa: Wydawnictwo Czarna Owca.

Witkowski L. (1998), Edukacja wobec sporów o (po)nowoczesność, Warszawa: Instytut Badań Edukacyjnych. 